\title{
Sensory cue, emotion, cognition and impulse buying behaviour of fast-food vendors in Ghana
}

\author{
Martey Edward Markwei ${ }^{1}$, Martey Racheal Markwei ${ }^{2}$ and Adenutsi Kingsford ${ }^{3}$ \\ ${ }^{1}$ Marketing department, Koforidua Technical University, Koforidua, Ghana. \\ Email:martey.edward@,ktu.edu.gh \\ 2Ematon consulting Ghana Limited. Email: Delcen36@gmail.com \\ 3Presbyterian University College, Ghana.Email: adenutsik@yahoo.com
}

${ }^{1}$ Correspondence: martey.edward@,ktu.edu.gh

\begin{abstract}
Fast food vendors use a sensory cue to trigger impulsive buying behaviour. Though impulse buying has gained interest among researchers, little has been done concerning food in Ghana. The purpose of the study was to investigate the contribution of the sensory cue on customer's emotions and cognition and impulsive buying behaviour. The study finds answers to the succeeding research questions: what sensory cue impacts on consumer emotion and cognition? And does emotion and cognition influence consumer's impulsive buying behaviour. A proposed theoretical model identifies visual, audio, and tactile dimensions as the sensory cue, emotions, and cognitive as mediation variable and impulsive buying behaviour as the outcome. Data were collected from 241 customers who were residence in Tema and have patronized the services of food vendors for a minimum of two years using a convenience sampling technique. The suggested hypothesis was tested using structural equation modeling and hierarchical multiple regression analysis. The result of the study shows that visual, audio, and tactile dimensions have a positive relationship with emotion but a negative relationship with cognition. Regarding directs effect, the study revealed that there is a positive relationship between emotion and impulsive buying behaviour whiles cognition has a negative effect on impulsive buying behaviour. The study recommended that managers must induce impulsive buying using characteristics of the food they serve and the environments in which they operate to stimulate customers' arousal and pleasure and provide enough information to alleviate the risk customers consider before buying food. The findings may not be generalized since the data was collected in specific areas in Tema.
\end{abstract}

Keywords: sensory cue; customer's emotion; cognition; impulsive buying behaviour.

Citation: Edward Markwei Martey, Racheal Markwei Martey and Kingsford Adenutsi. The influence of sensory cue on emotion, cognition and impulse buying behaviour of fast-food vendors in Ghana, 2020; 5(4): 12-29.

Received: October 23, 2020

Accepted: December 31, 2020 


\subsection{Introduction}

\subsection{Background}

Over the past decade, many researchers have tried to understand what triggers impulse buying behaviour. This is because customers assume that they are rational but, on many occasions, buy food without considering quality or price or time. (Eckman, \& Yan, 2011: Peck \& Childers, 2006; Stern, 1962, Chang, Rook, 1987;)

Studies have shown an association amongst sensory cues and impulse buying of food (Crouch, \& Ong, 2008). These claims have not been substantiated with scientific methods (Köster, 2009) or descriptive techniques (Murray, Delahunty, \& Baxter, 2001). Many food joints have sorted to using fresh scents to appeal to the emotions of customers to buy impulsively. However, it appears that food is cooked after orders have been placed and the smell is found during cooking

Aside from, smell Stroebele \& de Castro, (2004) explained that ambient sound influences the food choice of customers, but the extent of the effect is yet to be established. According to Tifferet and Herstein (2012), smell and taste also contribute to customers' impulse buying. But a very little experimental study has been conducted. Exposure to sensory cue leads to food temptation and triggers the impulse buying of food. This means that there is a need to investigate the link between sensory cues on impulse buying behaviour. Many customers do not know exactly how they are influenced by sensory stimulations (Chartrand, 2005). Sensors appeal to a customer's emotional mechanism to impulse buying behaviour. (Chang et al., 2011).

To stop the crack in literature, the study seeks to investigate empirically customer's impulsive buying behaviour. The study verified a conceptual model associated with emotional and cognitive tools on customer impulse buying behaviour. The study finds answers to the succeeding research questions: 1) What sensory cues impacts on consumer emotion and cognition? 2) Do emotion and cognition influence consumer's impulsive buying behaviour?

\section{Hypotheses of the study}

The study suggested the following hypotheses:

H1a.Visual dimension is positively related to emotions

$\mathrm{H} 1 \mathrm{~b}$ Visual dimension is positively related to cognition

H2a.Auditory dimension is positively related to emotions

H2b.Auditory dimension is positively related to cognition 
H3a.Tactile dimension is positively related to emotions

H3b.Tactile dimension is positively related to cognition

H4: Emotions are positively related to impulsive buying behaviour.

H5: Cognition is positively related to impulsive buying behaviour

\subsection{Empirical Literature}

\subsection{Theoretical framework}

\subsection{The theory of Heuristic and Systematic Processing}

The theory of Heuristic and Systematic Processing describes that persons are influenced by evidence and is thus valuable in appreciative of buying behaviour. The theory explained that customers decide they are either heuristic processing or systematic processing. Customers are persuading based on the content of the information. According to Trumbo, (1999) systematic strategies are used after customers have searched for information and have compared all the alternatives available. The information processed and understood is more persuasive than the source and credibility of the information (Chaiken, 1980). However, in the case of heuristic processing decision taken determines whether the information is valid (Trumbo, 1999). According to Grewal, \& Suri, (2013) Heuristic elements such as colour influences consumer decision making.

\subsection{Impulse Buying}

A study into impulse buying started from 145 to 1965 across different countries in the world by (Nemours and Company, 1965). It is a very essential area of study for theoretical and practical terms. Research scholars from economics and psychology have expressed interest in getting to know the causes of impulsive buying as customers claim they are rational in their buying (Dittmar, Beattie, \& Friese, 1996). One of the accepted definitions of impulsive buying is Rook (1987), who said, "experiencing a sudden, often powerful and persistent urge to buy something immediately" According to him, customers who buy impulsively are those who react to emotional appeals (Rook \& Gardner, 1993). Interestingly a customer does not have an interest in what results in such purchases (Dodd, 1997).

The framework for customer behaviour is always cut short when a customer buys quickly without fully observing the steps in the buying decision made against planned buying (Verplanken, Herabadi, Perry, \& Silvera, 2005). This shows that customers who buy impulsively are more triggered by what they see hear and feel than those who do plan buying. 


\subsection{Visual dimension}

A study into impulse buying started from 145 to 1965 across different countries in the world by (Nemours and Company, 1965). There is a link between visual stimuli and how customers perceive the product. This is because...visual send information to the brain. Marketers are using visuals because many customers trust what they see (Krishna, Cian\& Sokolova, 2016). One of the main atmospheric elements that affect a customer's mood at retail shops is visual cues (Brengman \& Geuens, 2003). Marketing practitioners are constantly using visual dimensions, such as lighting colour, and layout to inspire customers to visit and stay in their retail outlets, it also helps in differentiating one retail outlet from another.

\subsection{Auditory dimension}

Sound is a tool to communicate with customers (Bublitz \& Peracchio, 2009). Marketers create sounds at a retail outlet using music to induce customers to stay longer when shopping. Yorkston (2010) explained that lower music keeps customers more and shop more as compare to fast music. The volume of the music also affects customer behaviour. Customers stay fewer hours in shops with high music volume as compared to soft volume (Yorkston, 2010). To create favourable auditory experience marketer of retail outlet use music to communicate and arouse the subconscious of customers. (Meyers-Levy, Bublitz \& Peracchio, 2009).

\subsection{Tactile dimension}

According to Anil \& Merve, (2015), touching is an essential sense in assessing product at retail outlets. Customers are motivated to touch products at the store due to perception and experience (Kolter et al, 2016). Krishna (2010) categorizes touching of products into four different types. The first three touches have to do with the consumer engaged in pre-purchase behaviour which is called instrumental touch. Customers touch products to inspect or smell the product when they want to make a purchase.

Besides, some consumers touch products to obtain haptic product information, such as weight and the temperate of the product. And the fourth type is called hedonic touch. The goal of this touch is to generally explore the product and to have fun. Hedonic touch neither may or may not ultimately result in product purchase.

\subsection{Emotion and Cognition}

The two important areas of customer buying behaviour are Emotion and cognition. Customer buying behaviour always involves comparing alternatives and scarifies other brands to their benefit (Brunsø et al., 2002). There are many factors that affect the buying behaviour of customers, these include perception of quality cues and the information gathered while shopping. (Brunsø et al., 2002). There are many instances 
where customer's attention is attracted to sensory cue leading to thoughtless buying. This cannot be captured by the rational model of customer buying behaviour proposed by Canonica (Dubé et al., 2008). Emotion has a significant impact on buying behaviour of customers (Jang, Ha, \& Park, 2012)

Cognition is how customers acquire knowledge and use their memory (Fiore \& Kim, 2007). Cognition involves the interpretation of stimulus into meaningful representation. According to Holbrook and Hirschman (1982) what customers have in their mind affect what they buy.

The researcher selected three emotional variables (Visual, Audi, and Tactile dimensions) and one cognition variable, (perceived risk) because many scholars have done a few on these variables.

\subsection{Visual dimension emotion and cognition}

The brightness of a retail outlet strongly influences the degree of arousal of customers (Miwa \& Hanyu, 2006).Colours of the interior retail environment such as blue and green often arouse customers. (Dijksterhuis et al., 2005). Customer pleasure is also activated by the layout of stores (Mirabi \& Samiey, 2015).

When the available information alleviates fear and worries the customer will make a positive decision. Bonnet, Amalric, Chevé, \& Travers, (2012) explained that the visual display is processed into the memory of customers to determine the severity of consequences that are assessed from available information. In situations where the perceived risk is high customers may leave the premises of the organization

\subsection{Auditory dimension and emotion and cognition}

According to Van der Zwaag et al. (2012) there is no significant effect between music and arousal level, normally, music seems not to induce consumer's arousing feeling. Besides, Van der Zwaag et al. (2012) argued that a female consumer is more interested in retail environment. Without music playing. Therefore, it is proposed for retailers to prudently play music in their store, since music allows them to stimulate both a consumer's positive mood and a negative mood (Gancer \& Huda, 2010).

To sum up, whether a positive or negative emotional state, it influences the decisions on products or services (Solomon et al., 2013). In other words, if a consumer has a more positive mood that is enthused by the ambiance in a store, it would be keener to stay longer or even purchase products from the store It is said mood does have the power to influence how consumers think and behave (Babin, Darden \& Griffin, 1992; Donovan \& Rossiter, 1982).

The kind of music and the sound are evaluated by customers to determine the risk involved. Customers who perceive less risk of audio dimension are likely to sit longer at retail shops. Those who think the sound level is harmful to their eardrum or health will leave the shop (Morton \& Duck, 2001). 


\subsection{Tactile dimension and emotion and cognition}

According to Kolter et al, (2016) as customers touch products, it created images in their minds and connects with the quality of the product. In some cases, touching a product affect emotional response and leads to impulsive buying and unplanned purchase (Kolter et al, 2016). According to Essick, James, and McGlone (1999) tactile cues, such as products' physical attributes affect the customer's emotional reactions.

Peck \& Wiggins, (2006) explained that customers who touch or test a product react positively towards the product. In retail cosmetic shops, customers are given the opportunity to test or use the product and this brings positive reactions towards the product. (Theofanides \& Kerasidou, 2012). There are instances where the test of perfume at retail outlets persuades females into impulsive purchasing (Gannon, 2011). Many studies have confirmed that tactile cues trigger positive emotions, however, it has been established that unpleasant emotions are caused by the tactile cues (Saariluomaand \& Jokinen, 2014).

According to Taylor, (1974), customers enquire for further information when perceived risk is high. Tactile dimension alleviates customer risky buying decisions; however, few studies have shown the effect of product cues on perceived risk (Aqueveque, 2006; Chang \& Chen, 2008). The customer wants to touch and feel a product where the sensory cue makes the customer uncertain about what to buy. Most especially when the product in question is unfamiliar to the customer Tactile reduces the uncertainty through touching the product.

\subsection{Emotions (Arousal and Pleasure) and impulsive buying behaviours}

According to Kolter et al, (2016) as customers touch products, it created images in their minds and connects with the quality of the product. In some cases, touching a product affect emotional response and leads to impulsive buying and unplanned purchase (Kolter et al, 2016). According to Essick, James, and McGlone (1999) tactile cues, such as products' physical attributes affect the customer's emotional reactions.

Peck \& Wiggins, (2006) explained that customers who touch or test a product react positively towards the product. In retail cosmetic shops, according to Holbrook \& Hirschman, (1982) emotion is the driver of impulse buying behaviour. However, the emotional aspect of decision making has been less researched but interest in this regard is growing among researchers. Donovan and Rossiter (1982) classified emotion in two broad ways; arousal and pleasure, these two moderates the influence on impulsive buying behaviors.

When customers are aroused by a stimulus, they end up buying more impulsively. Therefore, arousal is a predictor of impulse buying behaviour (Lee \& Yi, 2008). Generally, literature has a mixed result on the influence of emotions (positive or negative) on impulse buying behaviour. According to the study by Aouinti, Mansali, and Zghal (2013), there is no significant link between arousal and impulse buying behaviour but rather pleasure has a significant link with impulse buying behaviour. 


\subsection{Cognition (Perceived Risk) and impulsive buying behaviour}

Cognition as a factor that influences impulsive buying behaviour is not clearly stated in early studies. Lee and Yi (2008) However, (Lee \& Yi, 2008) explained that perceived is a major factor in impulsive buying behaviour. When customers entrain perceived risk, it rather prevents them from buying impulsively. This means that a customer who sees risk in buying a product will hesitate in buying (Lee \& Yi, 2008). Customer's impulse buying behaviour changes as perceived risk change Mishra et al. (2014). All the above studies did not look at why customers buy again even after the perceived risk.

Based on the literature reviewed and hypothesis, the conceptual framework was developed in figure 1

Conceptual framework

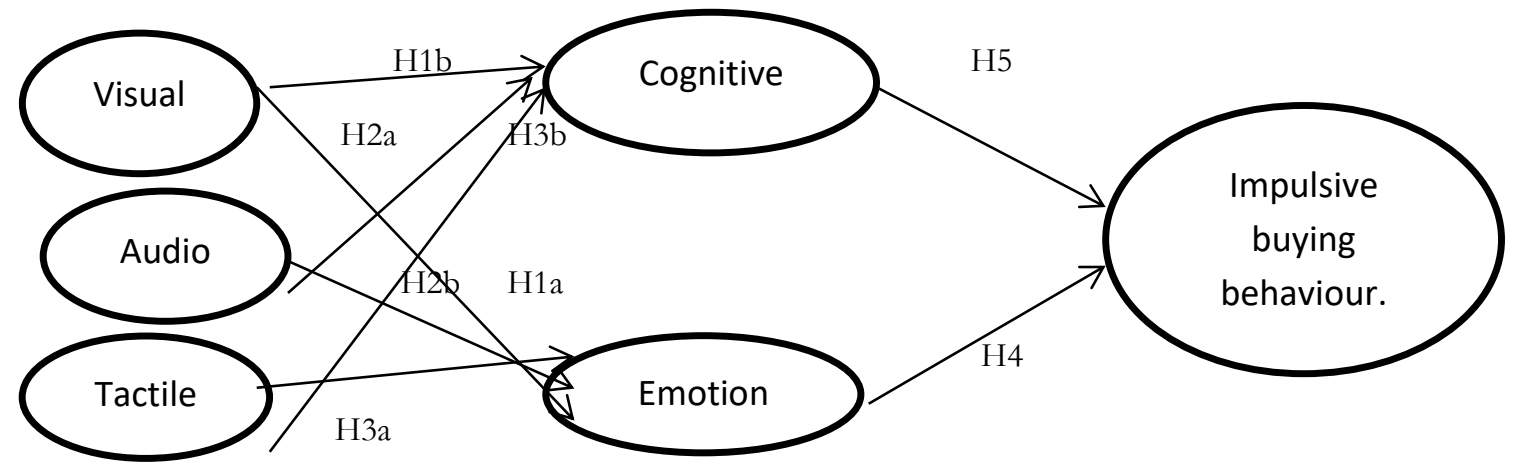

Figure 1 Conceptual framework

\subsection{Methodology}

\subsection{Sample}

The study adopted a convenience sample to select customers who are residing in Tema, Ghana who are more than 18 years old. The target population was customers who buy food on the street and restaurants. Tema was selected as the researcher had contact with the target population and food vendors are easy to come by. And 241 of respondents were used for the study after careful screening.

\subsection{Measure and Instrument Development}

The item was measured and validated using Likert5-Point -type scales ranging from strongly disagree to strongly agree. The sensory stimulus adopted was visual, Tactile, and Auditory was evaluated. Pleasure and arousal were adapted to measure customer emotions while the perceived risk was used to measure cognitive. 


\subsection{Data Collection}

The researchers used street- intercepts technique to access a customer's decision to buy food based on the sensory cue. Customers were given questionnaires to answer in the presence of the researchers. The data was collected on weekends between the hours of $10 \mathrm{am}$ and $4 \mathrm{p} \mathrm{m}$ on the street of Tema.

\subsection{Results}

The suggested hypothesis was tested using structural equation modelling and hierarchical multiple regression analysis.

Table 1 presents information for the three different fast-food vendors in Tema. Precisely, out of the 241 participants, 28.7 per cent $(n=61)$ are customers of Mayday, 32.3 per cent $(n=78)$ are customers of Papaye, 32.3 per cent $(n=78)$ are customers of KFC.

Table 1 Dataset of respondents' information

\begin{tabular}{|c|c|c|}
\hline & $\begin{array}{ll}\text { Response } & \text { distribution } \\
(\mathrm{n}=241) & \end{array}$ & Percentage \\
\hline Male & 150 & 62.2 \\
\hline $\begin{array}{l}\text { Female } \\
\text { Fast food }\end{array}$ & 91 & 37.8 \\
\hline Mayday & 69 & 28.7 \\
\hline $\begin{array}{l}\text { Papaye } \\
\text { KFC }\end{array}$ & 78 & 32.3 \\
\hline No of years & 94 & 39 \\
\hline 2 years & 79 & 32.8 \\
\hline Between 3- 6 years & 117 & 48.5 \\
\hline Between 7-10 years. & 45 & 18.7 \\
\hline
\end{tabular}

\section{Measurement Model Testing}

The measurement of the model was evaluated using confirmatory factor analysis, structural equation modeling technique. Table 2 shows the factor loading of the variable. 
Table 2 Measurement Items and Standardized Loadings

\begin{tabular}{|c|c|}
\hline \multirow[t]{2}{*}{ Constructs } & \multirow{2}{*}{$\begin{array}{l}\text { Standardized } \\
\text { Loading* }\end{array}$} \\
\hline & \\
\hline \multicolumn{2}{|l|}{ Auditory dimension } \\
\hline Music induces me stay longer & .0871 \\
\hline The volume of the music affects & 0.957 \\
\hline Lower music keeps me more at a shop. & 0.811 \\
\hline \multicolumn{2}{|l|}{ Tactile dimension } \\
\hline I touch product when they want to make purchase & 0.881 \\
\hline I hold a product to get haptic product information & 0.847 \\
\hline I hold a product to have fun. & 0.978 \\
\hline I hold products to formed images my minds & 0.847 \\
\hline \multicolumn{2}{|l|}{ Visual dimension } \\
\hline Visuals send information to my brains & 0.774 \\
\hline I trust what I see & 0.841 \\
\hline Colour, layout and lighting to inspire my to visit & 0.856 \\
\hline My pleasure is triggers by what I see & 0.917 \\
\hline \multicolumn{2}{|l|}{ Emotion Arousal } \\
\hline I sensed happy. & 0.895 \\
\hline I sensed joyful. & 0.853 \\
\hline I sensed roused. & 0.862 \\
\hline I sensed astonished. & 0.921 \\
\hline \multicolumn{2}{|l|}{ Perceived Risk } \\
\hline The food do not savour as I thought & 0.874 \\
\hline The food turned fine as my image. & 0.784 \\
\hline I paid a reasonable price for the food. & 0.941 \\
\hline My friends think extremely of me when I buy food & 0.794 \\
\hline Eating the food creates risk to my health or safety. & 0.874 \\
\hline \multicolumn{2}{|l|}{ Impulse Buying Behaviour } \\
\hline I buy food impulse. & 0.899 \\
\hline I buy food I had not originally planned to buy & 0.874 \\
\hline I humoured in impulsively buying the food & 0.847 \\
\hline
\end{tabular}


Factor loadings are significant at $\mathrm{p}<.001$.

The measurement items factor loading score were tested to ascertain the average variance extracted (AVE) values of each construct. All low factors loading below 0.7 were dropped.

Table 3 Descriptive Statistics

\begin{tabular}{|c|c|c|c|c|c|c|c|c|c|}
\hline & $\begin{array}{l}\text { No. } \\
\text { of } \\
\text { Items }\end{array}$ & $\begin{array}{l}\text { Mean } \\
\text { (Std. } \\
\text { dev.) }\end{array}$ & AVE* & $\begin{array}{l}\text { Auditory } \\
\text { dimension }\end{array}$ & $\begin{array}{l}\text { Tactile } \\
\text { dimension }\end{array}$ & $\begin{array}{l}\text { Visual } \\
\text { dimension }\end{array}$ & $\begin{array}{l}\text { Arousal } \\
\text { Pleasure }\end{array}$ & $\begin{array}{l}\text { Perceived } \\
\text { Risk }\end{array}$ & $\begin{array}{l}\text { Impulse } \\
\text { Buying } \\
\text { Behaviour }\end{array}$ \\
\hline Auditory & 3 & 4.68 & & & & & & & \\
\hline dimension & & & 0.67 & & & & & & \\
\hline Tactile & 4 & 3.89 & 0.58 & 0.87 & & & & & \\
\hline dimension & & & 0.69 & 0.76 & 084 & & & & \\
\hline Visual & 4 & 4.18 & 0.98 & & 0.77 & 0.78 & & & \\
\hline dimension & & & & 0.59 & 0.81 & & & & \\
\hline Arousal & 4 & 3.57 & 0.91 & & & 0.84 & 0.82 & & \\
\hline Pleasure & & & & 0.63 & & & & & \\
\hline Perceived & 5 & 4.12 & & & 0.69 & 0.81 & 0.73 & 0.75 & \\
\hline Risk & & & 0.64 & 0.87 & & & & & \\
\hline Impulse & 3 & 3.89 & & & 0.56 & 0.75 & 0.64 & 0,72 & 0.74 \\
\hline Buying & & & & 0.91 & & & & & \\
\hline Behaviour & & & & & & & & & \\
\hline
\end{tabular}

* $A V E=$ average variance extracted;

a Composite reliabilities are along the diagonal in bold;

$b$ Correlations are above the diagonal;

c Squared correlations are below the diagonal; $d$ The squared correlation of arousal-pleasure was bigher than the AVE of arousal. Discriminant validity was proved after fixing the correlation of a pair of arousal-pleasure on unity.

Table 3 shows the descriptive statistics (standard deviations and means), composite reliabilities, AVEs, correlations, and squared correlations of the constructs in this study. The result of AVEs on the entire construct exceeds 0.50 cut off point based on the findings of (Fornell and Larcker 1981). This explains that all the constructs have an accepted level of convergent validity. The composite reliability score for the entire construct is higher than the threshold value of 0.70 . It ranges from 0.74 to 0.87 ; this shows that there is adequate internal consistency (Bagozzi \& Yi, 1988). The researcher calculated the discriminant validity of the 
construct by comparing the AVE values with the squared correlations (R2) value of the respective pairs (Fornell \& Larcker, 1981). Bagozzi and Yi (1988) explained that there is a need to assure discriminant validity through the use of chi-square difference $\left(\Delta \chi^{2}\right)$ by equating $\chi^{2}$ of the original measurement model with $\chi^{2}$ of the model in which two constructs are correlated or constrained to unity (the constrained model).

The result shows that $\chi^{2}$ differences were $116.12(\mathrm{df}=1)$ for 'emotional at $\mathrm{p}<.001$. This shows that the constrained models are a poorer model fit index than the original measurement model.

\section{Structural Model and Relationship Test}

The construct of the suggested model was examined using SEM analysis. The result of the model fit was satisfactory at $(\mathrm{NFI}=.712$; $\mathrm{TLI}=.817$; CFI $=.745$; RMSEA $=.071)$, with chi-square statistic $\left(\chi^{2}=616.01\right.$; $\left.\mathrm{df}=181 ; \chi^{2} / \mathrm{df}=2.755 ; \mathrm{p}<.001\right)$. The standard path coefficient and the t-values at $\mathrm{p}<.05$ are shown in figure. 2

Hypothesis 1a advocated a positive connection between visual dimension and emotion; the hypothesis was supported $(\beta=.901 ; \mathrm{t}=14.01 ; \mathrm{p}<.001)$.

Hypothesis $1 \mathrm{~b}$ proposed a positive relationship between visual dimension and cognition; nevertheless, the hypothesis was not supported $(\beta=-.300 ; \mathrm{t}=-4.01 ; \mathrm{p}<.001)$

Hypothesis $2 \mathrm{~b}$ suggested a positive connection between Auditory dimension and emotion; the hypothesis was supported $(\beta=.804 ; \mathrm{t}=16.09 ; \mathrm{p}<.001)$.

Hypothesis $3 \mathrm{~b}$ proposed a positive relationship between Auditory dimension and cognition; nevertheless, the hypothesis was not supported $(\beta=-.404 ; \mathrm{t}=-5.05 ; \mathrm{p}<.001)$

Hypothesis 3a, guessed a positive linking between Tactile dimension and emotion the hypothesis was supported $(\beta=.943 ; \mathrm{t}=17.682 ; \mathrm{p}<.001)$,

Hypothesis 3b, proposed positive relationship between tactile dimension and cognition; the hypothesis was not supported $(\beta=.-204 ; \mathrm{t}=-5.30 ; \mathrm{p}<.001)$, thus supporting Hypothesis $2 \mathrm{~b}$.

Hypothesis 4 suggested a positive connection between emotion and impulsive buying behaviour. The result supported the hypothesis at $(\beta=.660 ; \mathrm{t}=16.06 ; \mathrm{p}<.001)$,

Hypothesis 5, proposed a positive relationship between cognitive and buy impulsively buying behaviour. Hypothesis 5 was not supported $(\beta=.-205 ; \mathrm{t}=-421 ; \mathrm{p}<.01)$. 
Test Results of the Proposed Relationships

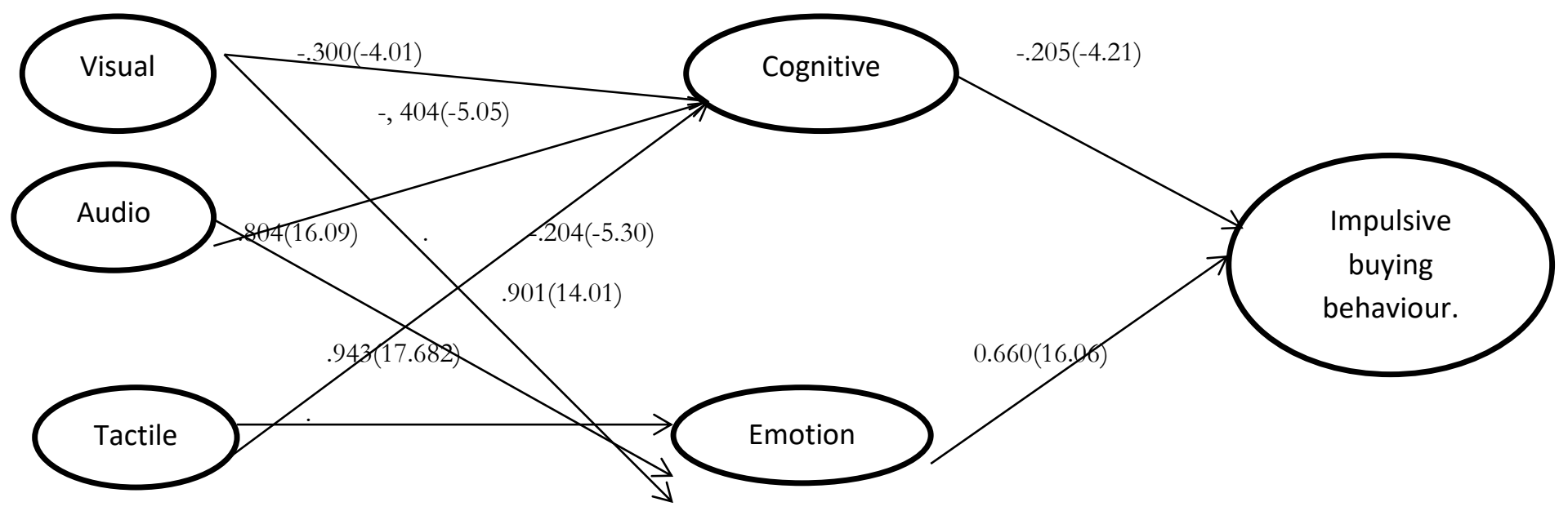

Figure 2 Test Results of the Proposed Relationships

Note. Numbers in parentheses are the t-values; Numbers outside of parentheses are the standardized path coefficients; the dotted arrow indicates an insignificant path $(p>.05)$.

Test of Indirect Relationships

The researchers decided to investigate the indirect association of stimulus cues and impulsive buying behaviour. To do this the researcher tested the moderating variables: customer emotion and cognitive and the stimulus and the moderating variable and impulsive buying behaviour. The study adopted Baron and Kenny's (1986) mediation analysis, the chi-square $\left(\chi^{2}\right)$ difference test, the Sobel test, and the bootstrapping test to examine the model

The researcher conducted the mediating analysis in four different stages. The researcher conducted the mediating analysis in four different stages. 
Table4 direct path amongst the stimulus cues and the mediator

\begin{tabular}{|c|c|c|c|c|c|}
\hline \multirow[t]{2}{*}{ Mediators } & \multirow[t]{2}{*}{ Amongst } & \multicolumn{4}{|c|}{$\begin{array}{l}\text { Statistics of } \mathrm{Pa} \square \mathrm{Ob} \text {, } \\
\text { when } \mathrm{Mc} \square \square \mathrm{O} \text { is set at } 0 .\end{array}$} \\
\hline & & B & S.E. & 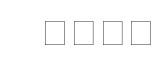 & $\mathrm{t}$ \\
\hline \multirow[t]{3}{*}{$\mathrm{CE}$} & VD & 0.87 & 0.58 & 0.77 & $10.650^{* * *}$ \\
\hline & $\mathrm{AD}$ & 0.85 & 0.59 & 0.78 & $11.001 * * *$ \\
\hline & TD & 0.88 & 0.55 & 0.74 & $11.209 * * *$ \\
\hline \multirow[t]{3}{*}{$\mathrm{CN}$} & VD & 0.76 & 0.52 & 0.71 & $10.109 * * *$ \\
\hline & $\mathrm{AD}$ & 0.79 & 0.53 & 0.71 & $13.402 * * *$ \\
\hline & TD & 0.77 & 0.50 & 0.72 & $9.802^{* * *}$ \\
\hline
\end{tabular}

The table 4 shows the direct path from customer emotions and cognitive on the stimulus cue. The path from visual dimension to customer emotion is significant at $\mathrm{p}<.001\left(\beta=.87 ; \mathrm{t}=10.650^{* *} ; \mathrm{p}<.001\right)$. Also, the direct influence of auditory dimension on customer emotion is significant at $\mathrm{p}<.001(\beta=0.78 ; \mathrm{t}=11.001 * *$; $\mathrm{p}<.001)$.

The direct effect of Tactile dimension on customer emotions shows a significant relationship at $\mathrm{p}<.001(\beta=$ $\left.0.74 ; \mathrm{t}=11.209^{* * *} \mathrm{p}<.001\right)$. Besides, visual dimension on cognitive has a significant relationship at $\mathrm{p}<.001$ $(\beta=0.71 ; \mathrm{t}=10.109 * * \mathrm{p}<.001)$.

The direct effect of auditory dimension on cognition is evaluate at $\mathrm{p}<.001\left(\beta=0.71 ; \mathrm{t}=13.402^{* * *} \mathrm{p}<.001\right)$ and Tactile dimension on customer emotions shows a significant $\mathrm{p}<.001\left(\beta=0.72 ; \mathrm{t}=9.802^{* *} ; \mathrm{p}<.001\right)$.

Table 5 direct path amongst the Stimulus and impulsive buying behaviour

\begin{tabular}{|c|c|c|c|c|c|}
\hline \multirow[t]{3}{*}{ Mediator } & \multicolumn{5}{|c|}{ Amongst } \\
\hline & & \multicolumn{4}{|c|}{ Statistics of $\mathrm{Pa} \square \mathrm{Ob}$, } \\
\hline & & \multicolumn{4}{|c|}{ When Mc $\square \square \mathrm{O}$ is set at 0 . } \\
\hline $\mathrm{CE}$ & IBB & B & S.E. & $\square \square \square \square$ & $\mathrm{t}$ \\
\hline \multirow[t]{2}{*}{$\mathrm{CN}$} & $1 \mathrm{BB}$ & 0.72 & 0.67 & 0.81 & $15.45^{* * *}$ \\
\hline & & -0.25 & 0.61 & 0.72 & $-9.031 * * *$ \\
\hline
\end{tabular}

Table 5 shows the relationship between the mediator and the outcome variable using the path coefficient. The direct path from emotions to impulsive buying behaviour was fixed to zero and recorded a significant $\mathrm{p}$ 
$<.001\left(\beta=0.72 ; \mathrm{t}=9.802^{*} ; \mathrm{p}<.001\right)$. The relationship between cognitive and impulsive buying behaviour was positive nevertheless, the hypothesis was not supported $(\beta=--0.25 ; \mathrm{t}=-9.031 * * * ; \mathrm{p}<.001)$.

Table 6 the direct effect of stimulus cues, mediator, and impulsive buying behaviour

\begin{tabular}{llll}
\hline Mediating role of & Between & & \\
& & Decreased in $\chi^{2}$ \\
& & $\mathrm{~B}$ & \\
$\mathrm{CE}$ & $\mathrm{IBB}$ & $3.793 \mathrm{~ns}$ & \\
$\mathrm{CN}$ & $1 \mathrm{BB}$ & 5.45 & \\
$\mathrm{SM}$ & $1 \mathrm{BB}$ & 4.56 & \\
\hline
\end{tabular}

The study adopted nested model technique by Anderson and Gerbing (1988) to establish that the model with moderation variable has a better fi than those without moderation. The model without the moderating model was related and examined using the $\chi^{2}$ statistic. In a case where the non-mediating model is better than the non- mediating model, the difference of the $\chi^{2}$ statistic should be significant (3.84 of $\Delta \chi^{2}$ or more at the $\mathrm{p}<$ .05 level: Byrne, 1998).

The mediating model with customer emotion as a mediator between stimulus and impulsive buying behaviour indicated 6.07 of $\chi^{2}$ changes, significant at the $\mathrm{p}<.05$ level. Besides, cognitive as a mediator between stimulus and impulsive buying behaviour failed to reveal significant changes in $\chi^{2}$ when likened to the nonmediation models for one decreasing degree of freedom.

\section{Discussion and Implications}

This study used heuristic and systematic processing theory to solve the research question: 1) what food sensory influences consumer emotion and cognition? 2) Do emotion and cognition influence consumer's impulsive buying behaviour.

From the literature reviewed and data analyzed, it comes out that, visual, audio, and tactile dimensions have a positive effect on customer emotions: pleasure and arousal while cognitive (perceived risk) is reduced by the visual, audio, and tactile dimensions. The finding is parallel to previously reviewed literature by Hultén et al., (2009) whose findings established that visual, audio, and Tactile dimensions influences both emotions and cognitive. Besides, the study by Morrin and Chebat (2005) also confirmed that sensory cue impacts positively on both emotion and cognition. This study result shows that perceived risk among customers is reduced by a sensory cue that customers are exposed to. Sensory cue is the source of information to customers buy 
impulse. In situations where the information has less perceived risk in the minds of customers, it leads to impulsive buying.

Managers of this food outlet must put more effort into sending enough watering information as possible to the prospective customer through soft music, pleasant smell eye-catching visuals to send a signal to the customer that he or she has a psychological comfort. The restaurant must display pictorial images of the food served at the restaurant to capture the eyes of buyers on the street to stimulate impulsive buying.

It has been realized that as customers are aroused by sensory cues, there is is also a perceived risk aspect that discourages impulsive buying behaviour. As managers stimulate the emotions of customers, there is a need to demonstrate to customers that it is less risky to buy from them. This will urge impulsive buying behaviour. There is a perception of the health-related danger of consuming food on the street. Displaying the nutritional content of ingredients in terms of calories, fat, etc. will reduce fear.

Also, the study found out that, sensory stimulus and impulsive buying behaviour is best explained by emotions and cognition.

Impulsive buying behaviour is mediated by arousal, pleasant (customer emotion), and perceived risk (cognition). When the mediating variables are integrated into the model developed by the researcher, it explains what customers go through when they are exposed to a stimulus before they finally make impulsive buying decisions.

The study recommended that managers who will want to induce impulsive buying must muse the characteristics of the food they serve and the environment in which they operate to stimulate customers' arousal and pleasure and provide enough information to alleviate the risk customers consider before buying food.

\section{References}

Aouinti, N., Mansali, O. B., \& Zghal, M. (2013). Social environment, emotions, and impulse buying: A meditational analysis. Journal Research in Marketing, 1, 55-61.

Anić, I.-D., Rajh, S. P., \& Rajh, E. (2014). Antecedents of food-related consumer decision-making styles. British Food Journal, 116, 431-450. 
Baron, R. A., Byrne, D., \& Kantowitz, B. H. (1980). Psychology: Understanding behavior (2nd ed.). New York, NY: Holt, Rinehart \& Winston.

Bagozzi, R. P., \& Yi, Y. (1988). On the evaluation of structural equation models. Journal of the Academy of Marketing Science, 16, 74-94.

Baumeister, R. F. (2002). Yielding to temptation: Self-control failure, impulsive purchasing, and consumer behavior. Journal of Consumer Research, 28, 670-676.

Bellenger, D. N., Robertson, D. H., \& Hirschman, E. C. (1978). Impulse buying varies by products. Journal of Advertising Research, 18, 15-18.

Brunsø, K., Fjord, T. A., \& Grunert, K. G. (2002). Consumers' food choice and quality perception (Working Paper No. 77). Aarhus, Denmark: Aarhus University, School of Business.

Chang, H.-J., Eckman, M., \& Yan, R.-N. (2011). Application of the stimulus-organism-response model to the retail environment: The role of hedonic motivation in impulse buying behavior. The International Review of Retail, Distribution and Consumer Research, 21, 233-249.

Chaiken, S. (1980). Heuristic versus systematic information processing and the use of source versus message cues in persuasion. Journal of Personality and Social Psychology, 39, 752-766.

Chartrand, T. L. (2005). The role of conscious awareness in consumer behavior. Journal of Consumer Psychology, 15, 203-210.

Choi, J., Lee, A., \& Ok, C. (2013). The effects of consumers' perceived risk and benefit on attitude and behavioral intention: A study of street food. Journal of Travel \& Tourism Marketing, 30, 222-237.

Costell, E., Tárrega, A., \& Bayarri, S. (2010). Food acceptance: The role of consumer perception and attitudes. Chemosensory Perception, 3, 42-50.

Dholakia, U. M. (2000). Temptation and resistance: An integrated model of consumption impulse. Psychology \& Marketing, 17, 955-982.

Dodd, T. H. (1997). Techniques to increase impulse wine purchases in a restaurant setting. Journal of Restaurant \& Foodservice Marketing, 2, 63-73.

Donovan, R. J., \& Rossiter, J. R. (1982). Store atmosphere: An environmental psychology approach. Journal of Retailing, 58, 34-57. 
Dijksterhuis, A., Smith, P. K., van Baaren, R. B., \& Wigboldus, D. H. J. (2005). The unconscious consumer: Effects of environment on consumer behavior. Journal of Consumer Psychology, 15, 193-202. 13

Fornell, C., \& Larcker, D. F. (1981). Evaluating structural equation models with unobservable variable and measurement error. Journal of Marketing Research, 18, 39-50.

Hair, J. F., Black, W. C., Babin, B. J., \& Anderson, R. E. (2010). Multivariate data analysis. (7th ed.). Upper Saddle River, NJ: Prentice Hall.95

Holbrook, M. B., \& Batra, R. (1987). Assessing the role of emotions as mediators of consumer responses to advertising. Journal of Consumer Research, 14, 404-420.

Holbrook, M. B., \& Hirschman, E. C. (1982). The experiential aspects of consumption: Consumer fantasies, feelings, and fun. Journal of Consumer Research, 9, 132-140.

Hultén, B., Broweus, N., \& van Dijk, M. (2009). Sensory marketing. Basingstoke, UK: Palgrave Macmillan.

Jang, S., Ha, J., \& Park, K. (2012). Effects of ethnic authenticity: Investigating Korean restaurant customers in the U.S. International Journal of Hospitality Management, 31, 990-1003.

Kacen, J. J., Hess, J. D., \& Walker, D. (2012). Spontaneous selection: The influence of product and retailing factors on consumer impulse purchases. Journal of Retailing and Consumer Services, 19, 578-588.

Lee, G. Y., \& Yi, Y. (2008). The effect of shopping emotions and perceived risk on impulsive buying: The moderating role of buying impulsiveness trait. Seoul Journal of Business, 14, 67-92.

Lee, J.-S., \& Back, K.-J. (2009). An examination of attendee brand loyalty: Understanding the moderator of behavioral brand loyalty. Journal of Hospitality \& Tourism Research, 33, 30-50.

Luo, X. (2005). How does shopping with others influence impulsive purchasing. Journal of Consumer Psychology, 15, 288-294.

Machleit, K. A., Kellaris, J. J., \& Eroglu, S. A. (1994). Human versus spatial dimensions of crowding perceptions in retail environments: A note on their measurement and effect on shopper satisfaction. Marketing Letters, 5, 183-194.

Murray, J. M., Delahunty, C. M., \& Baxter, I. A. (2001). Descriptive sensory analysis: Past, present and future. Food Research International, 34, 461-471. 
Peck, J., \& Childers, T. L. (2008). If it tastes, smells, sounds, and feels like a duck, then it must be a....: Effects of sensory factors on consumer behaviors. In C. P. Haugtvedt, P. M. Herr, \& F. R. Kardes (Eds.), Handbook of consumer psychology (pp. 193-219). New York, NY: Psychology Press.

Pliner, P., \& Hobden, K. (1992). Development of a scale to measure the trait of food neophobia in humans. Appetite, 19, 105-120.

Powell, D., Brodber, E., Wint, E., \& Campbell, V. (1990). Street foods of Kingston. Mona, Jamaica: University of the West Indies, Institute of Social and Economic Research.

Rook, D. W., \& Hoch, S. J. (1985). Consuming impulses. In E. C. Hirschman \& M. B. Holbrook (Eds.), Advances in Consumer Research, Vol. 12 (pp. 23-27). Provo, UT: Association for Consumer Research.

Ryu, K., \& Jang, S. (2008). Influence of restaurants' physical environments on emotion and behavioral intention. The Service Industries Journal, 28, 1151-1165.

Sobel, M. E. (1982). Asymptotic confidence intervals for indirect effects in structural equation models. In S. Leinhardt (Ed.), Sociological methodology (pp. 290-312). San Francisco, CA: Jossey-Bass.

Taylor, J. W. (1974). The role of risk in consumer behavior. Journal of Marketing, 38, 54-60.

Trochim, W. M. K., \& Donnelly, J. P. (2008). The research methods knowledge base (3rd ed.). Mason, OH: Atomic Dog Publishing.

Verplanken, B., Herabadi, A. G., Perry, J. A., \& Silvera, D. H. (2005). Consumer style and health: The role of impulsive buying in unhealthy eating. Psychology and Health, 20, 429-441.

Youn, S., \& Faber, R. J. (2000). Impulse buying: Its relation to personality traits and cues. Advances in Consumer Research, 27, 179-185.

Yang, Z. J., Ho, S. S., \& Lwin, M. O. (2014). Promoting preventive behaviors against influenza:Comparison between developing and developed co

Zillmann, D. (1988). Mood management: Using entertainment to full advantage. In L. Donohew \& H. E. Sypher (Eds.), Comm. 